\title{
Hedging On U.S. Export Pricing: An Exchange Rate Pass-Through Analysis
}

\author{
Jui-Chi Huang \\ Division of Engineering, Business, and Computing \\ Pennsylvania State University Berks Campus \\ Reading, PA 19610, U.S.A. \\ E-mail: jxh74@psu.edu \\ Tantatape Brahmasrene \\ College of Business, Purdue University North Central \\ Westville, IN 46391-9528, U.S.A. \\ E-mail: tapeb@pnc.edu
}

\begin{abstract}
This paper investigates the impact of hedging activities on U.S. export pricing. A theoretical framework of export pricing model with a hedging component was derived to test the hypothesis via exchange rate pass-through. The hypothesis is that a firm with a high (low) hedging engagement would have a low (normal) degree of exchange rate pass-through, ceteris paribus. Two measurements of the hedging engagement are the hedging amount and the hedging dummy. The result tested with the hedging amount on pass-through supports the hypothesis and suggests the importance of hedging involvement in preventing any uncertainty from exchange rate fluctuations. In addition, the coefficient estimate of the foreign demand elasticity interacting with one-year-lagged exchange rate is significant at one percent. However, the differential effects of different levels of hedging activities on the size of pass-through with the hedging dummy are inconclusive.
\end{abstract}

Keywords: Hedging, Exchange rate uncertainty, Pass-through

\section{Introduction}

The floating exchange rate system has presented a risk to trade participants since 1971. From this perspective, the determinants of export pricing behavior may be obscured by the introduction of currency conversion risk. Furthermore, the exchange rate regime is country specific. The different levels of exchange risk arising from different export destinations demand different pricing strategies. The effect of currency exchange rate fluctuations on pricing behavior has been extensively studied since the 1970s in exchange rate pass-through literature. The objective of this study is to examine the impact of exchange rate uncertainty on exchange rate pass-through, and to show why the hedging behavior is an essential element in international pricing models.

When the contract is denominated in the destination country's currency, an appreciation of exporter's currency over the contract period may create a currency conversion loss to the exporter. In this case, the exporter can choose to:

- pass the currency conversion loss completely into its own currency prices in the next contract (complete exchange rate pass-through in exporter's currency or zero pass-through in destination country currency), or

- absorb the loss to keep its price unchanged (zero pass-through in exporter's currency or complete pass-through in destination country currency), or

- have some combination of the two (incomplete pass-through).

However, the incomplete exchange rate pass-through phenomenon may be caused theoretically by the misunderstanding of product differentiation or market structure, and empirically by the non-stationarity property of time-series data, simultaneity functional structure, dynamic adjustment, asymmetric response to exchange rates and costs, aggregation bias and data proxies.

Following Dornbusch (1987)'s industrial organization approach, the "new trade theory" has contributed to answer exchange rate pass-through question in terms of using the micro-foundation of the features of product differentiation, imperfect substitution and competition; and has advanced the understanding of pass-through relations. However, the empirical evidence is far from satisfactory. In addition to the known determinants of 
industrial characteristics and market structures to the incomplete exchange rate pass-through, hedging activities may also contribute to the mix as well.

\section{Literature Review}

Although there has been much empirical research on exchange rate pass-through, there does not seem to be much theoretical or empirical literature on the role of exchange rate volatility and hedging on pass-through.

\subsection{Exchange Volatility and Pass-Through}

Hooper and Kohlhagen (1978) studied the effect of exchange rate volatility on export pricing. Their theoretical work led to the conclusion that an increase in uncertainty increases prices when products are invoiced in foreign currency and thus reduces trade flows, assuming risk aversion. However, they found that the effect of exchange rate volatility on prices is ambiguous, and depends on the invoicing currency and the size of forward contract coverage.

The exchange risk affects the firm's expected profits and thus the firm's pricing decisions of the traded goods (Giovannini, 1988). When export prices are set in domestic currency, expected profits vary with exchange risk and expected profits might actually increase, leading firms to lower export prices. Mann (1989) confirms this finding and has proven that the exchange rate volatility can affect the degree of pass-through via the secondary effect of the exchange rate volatility. This means that the exchange risk faced by one trading party would eventually be transmitted to the other through trade contract negotiations.

Furthermore, Parsley and Cai (1995) studied the effects of exchange rate uncertainty on prices in an intertemporal context - tradeoffs between current and expected future exchange rate volatility. In their forward looking model, expectations of future volatility affected current pricing decisions. Under this intertemporal consideration, firms may choose not to pass through increases in exchange rate volatility to prices (zero pass-through). Specifically, when firms believe that current exchange rate volatility is temporary or independent from future volatility, they find that an increase in volatility does not lead to an increase in prices. This finding weakens the Hooper and Kohlhagen (1978)'s study in which trade is invoiced in the destination's currency and an increase in exchange rate volatility unambiguously raises prices.

In a theoretical work and simulation, Chang and Lapan (2003), developed a price competition game in which exchange rate uncertainty may lead to the emergence of a unique Nash equilibrium. This result occurs because exchange rate uncertainty may cause one or both firms to adopt the strategic pricing under a duopoly framework. Their theory explains that some exporters set prices before the realization of the nominal exchange rates as they face different degrees of exchange rate uncertainty. That is, each firm has the opportunity to set prices before the exchange rate uncertainty is resolved, or to defer setting prices until exchange rates are known.

\subsection{Hedging and Pass-Through}

Feenstra and Kendall (1991) examined the link between the estimated risk premium (the engagement in preventing the exchange risk) and the influence of exchange rate volatility on export prices for the U.S. trade with Japan, U.K. and Germany. If the risk premium is present, then the effect of exchange rate volatility on export prices is ambiguous due to the presence of the risk premium. If the risk premium is insignificant, the exchange rate volatility has a negative effect on prices (non-zero pass-through).

Huang and Brahmasrene (2004) explored the impact of corporate hedging on export prices, and found some evidence that the impact of exchange rates on export prices are weakened by the engagement of hedging activities. Primary product trade sectors are more competitive and therefore are more likely to engage in financial hedging activities to reduce foreign exchange risk than the manufacturing industry. Their analysis also shows moderate evidence that hedging activities in large trade sectors effectively reduce the trade costs - the exchange risk.

\section{Hypothesis and Empirical Specifications}

Based on the review of the studies on exchange rate volatility, hedging, and pass-through, the higher the exchange risk, due to the risk aversion, the more likely the trade agents would hedge against the risk in advance. Therefore, the degree of pass-through would be small in a currency risky environment. This study takes this observation into account and investigates the relationship between hedging and export pricing via the methodology of exchange rate pass-through.

Previous studies assume homogeneity and perfect competition. The law of one price states that prices of goods are equalized in different market locations while arbitraged geographically and adjusted for trade costs. Let $\mathrm{P}, \mathrm{P}^{*}$, and E denote the home currency price of goods in home country, the foreign currency price of goods in foreign country, and the foreign currency price of home currency exchange rate, respectively. The law of one price then implies: 
(1) $\quad \mathrm{P}^{*}=\mathrm{PE}$.

Equation (1) can be presented in the logarithm transformation with lower case italic as follows:

(2) $p=-e+p^{*}$

(3) $e=-p+p^{*}$

Equation (2) is a crude model of a monetary-approach exchange rate determination with $e$ being endogenous and $p$ and $p^{*}$ being exogenous. Equation (3) is a crude model of an exchange rate pass-through with only $p$ being endogenous and $e$ and $p^{*}$ being exogenous. These two crude models assume that the trade participants are risk-neutral. With the risk-neutrality assumption, particularly in the case of the crude model of exchange rate pass-through, the prices are adjusted in response to the changes in exchange rates, but not to the exchange risk. This happens because the risk-neutral trade agents do not differentiate in setting prices whether the exchange risk is high or low.

Empirically, the currency risk has been incorporated into equation (2) as the foreign exchange risk premium has been extensively studied and modeled in the literature of exchange rate determinations. Theoretical work of Engel (1999), Obstfeld and Rogoff (1998), and Devereux and Engel (1998) assumed a constant relative risk aversion of consumers as a demand side argument. In contrast, in spite of the endogeneity and the causality issues faced by conventional pass-through models, the currency conversion risk has not been focused on in modeling the pass-through relations. This study follows along this line in developing a hedging-augmented pass-through model.

The theoretical model begins with the idea of markup adjustments in Hooper and Mann (1989) and Mann (1986), and extends the pass-through framework of Knetter (1989) and Branson and Marston (1989) to explicitly focus on the connection between the risk aversion of exporters and their pricing behaviors. The assumption of risk aversion by export agents ensures that any trade risk including exchange risk would be managed and avoided by some financial instruments - the hedging activities. The direct relationship between hedging activities and the degree of exchange rate pass-through is hypothesized as:

- $\quad$ A firm with a high (low) hedging engagement would have a low (normal) degree of exchange rate pass-through, ceteris paribus.

A normal level of exchange rate pass-through means that without any protection of hedging or prevention from exchange risk the degree of pass-through depends on the level of competition. A firm facing a high exchange risk environment is more likely to elect to hedge its trade returns to forward markets or other means. Thus, the contract value is less likely to be affected by exchange risk. As a result, pass-through would be low. On the other hand, a firm facing a low exchange risk environment will be less likely to hedge its trade returns, so the degree of pass-through is not distorted and would be at a normal level, depending on the product differentiation and market structure.

The empirical model assumes imperfect substitutability and competition in foreign destination markets so that the export demand depends on the destination-currency prices of exports and local competitors, and demand shifters. With the crude pass-through model in equation (3), the empirical export pricing model (Huang \& Brahmasrene, 2009) can be derived and specified as:

(4) $\quad p_{i c t}=\beta_{0}+\beta_{1} e_{c, t-1}+\beta_{2} p_{c t}^{f}+\beta_{3} g d p_{c t}^{f}+\beta_{4} p c_{i, t-1}+\beta_{5} p g_{t}+\mu_{i c t}$.

where all variables are in natural logarithm and in lower case italic; and

$i=$ the 4-digit 1972-based Standard Industrial Classification (SIC) industry;

$c=$ export destination country;

$t=$ time;

$p_{i c t}=$ U.S. unit export values denominated in U.S. dollars by 4-digit SIC and by country destination over time;

$e_{c, t-1}=$ one-year lagged annual bilateral nominal exchange rates;

$p_{c t}^{f}=$ prices of foreign competing goods measured by destination consumer price index;

$g d p_{c t}^{f}=$ annual destination Gross Domestic Product in destination currency as a demand shifter;

$p c_{i, t-1}=$ one-year lagged annual U.S. producer price index including unit labor, raw material and energy costs by 4-digit SIC;

$p g_{t}=$ U.S. productivity growth over time;

$\mu_{i c t}=$ error term. 
$\beta_{I}$ is usually termed as the pass-through elasticity, which measures the degree of exchange rate pass-through to the producer-currency export prices. Normally, it is between -1 and 0 . Based on the above hypothesis, the degree of pass-through $\left(\beta_{l}\right)$ is a function of hedging activities $\left(h g_{i t}\right)$. Therefore, the equation (5) below is the hedging pass-through model:

(5) $\beta_{1}=\gamma_{0}+\gamma_{1} h g_{i t}+\gamma_{2}\left|\varepsilon_{x, i t}^{d}\right|+v_{i c t}$.

where the lower case is the logarithm values of variables; and

$\beta_{1}=$ estimated value of pass-through elasticity;

$h g_{i t}=$ hedging activities by each SIC industry over time;

$\left|\varepsilon_{x, i t}^{d}\right|=$ export elasticity of demand, capturing the competitive pressures;

$v_{i c t}=$ error term.

$\gamma_{1}>0$ shows that the more hedging activities the trading agents engage $\left(h g_{i t} \uparrow\right)$, the lower will be the pass-through $\left(\beta_{1} \uparrow\right.$, note that $\beta_{I}$ is negative); $\gamma_{I}<0$ means that if the export demand is more inelastic $\left(\left|\varepsilon_{x, i t}^{d}\right| \downarrow\right)$, then exporters have more market power to pass through, hence pass-through is higher $\left(\beta_{I} \downarrow\right)$.

If equations (4) and (5) were run separately, heteroscedasticity would be induced and the estimated coefficients would be inefficient. Therefore, equation (5) is tested simultaneously with equation (4) by substituting equation (5) into equation (4). As a result, the main empirical export pricing model with the hedging component becomes:

$$
\text { (6) } p_{i c t}=\alpha_{0}+\alpha_{1} e_{c, t-1}+\alpha_{2}\left[h g_{i t} e_{c, t-1}\right]+\alpha_{3}\left[\left|\varepsilon_{x, i t}^{d}\right| e_{c, t-1}\right]+\alpha_{4} p_{c t}^{f}+\alpha_{5} g d p_{c t}^{f}+\alpha_{6} p c_{i, t-1}+\alpha_{7} p g_{t}+\xi_{i c t} \text {. }
$$

To validate the hypothesis, the negative relationship between the hedging activities $\left(h g_{i t}\right)$ and the degree of pass-through $\left(\beta_{1}\right)$ can be estimated through $\alpha_{2}>0$ in equation (6) along with the interaction term, $\left[h g_{i t} e_{c, t-1}\right]$.

\section{Sample Data Collection and Research Design}

In this section, data descriptions and their sources are explored, evaluated and documented. When the firms are more trade focused, there is a greater possibility that they will hedge the trade value. On this note, the research design is calibrated into two different groups namely the highest export share and the lowest export share.

\subsection{Data Collection}

To compute the export elasticity of demand, the U.S. unit export values denominated in U.S. dollars and quantities by 4-digit SIC and country destination over time can be found in the data center of National Bureau of Economic Research (NBER), (http://www.nber.org/data/) or in the Center for International Data at UC Davis (http://www.internationaldata.org/). One-year lagged annual bilateral nominal exchange rates are from the International Financial Statistics, International Monetary Fund (http://ifs.apdi.net/).

The consumer price index and an annual destination Gross Domestic Product in destination currency are collected from the World Development Indicators, World Bank, (http://devdata.worldbank.org/dataonline/). One-year lagged annual U.S. producer price index including unit labor, raw material and energy costs by 4-digit SIC are collected from the Bureau of Labor Statistics, U.S. Department of Labor (http://www.bls.gov/data/home.htm). The U.S. productivity growth data are from the NBER-U.S. Census Bureau's Center for Economic Studies (CES), Manufacturing Industry 1958-1996 Database (http://www.nber.org/nberces/).

Furthermore, the industry export share is defined as export value over the domestic shipment by each 4-digit SIC industry over time. The variable is calculated from the export value data and the U.S. domestic shipments data. The U.S. domestic shipments data also are from the NBER-CES Manufacturing Industry 1958-1996 Database (http://www.nber.org/nberces/).

The hedging data is retrieved from the EDGAR database (http://www.sec.gov/cgi-bin/srch-edgar) which is maintained by the U.S. Securities and Exchange Commission (SEC, http://www.sec.gov/). The website archives contain the company filings from 1994. All foreign or domestic companies in the U.S. are required to file registration statements, periodic reports, and other forms electronically through EDGAR. Form 10-K reports the company's use of any financial instruments to avoid risks from interest rates or currency exchange rates.

\subsection{The Research Design}

Based on 1972-SIC industries, the hedging data are collected on the 10 highest export share (Table 1), and the 10 lowest export share (Table 2). The main difference between these two export share groups is designed to be a proxy of the difference between the firms with more and less trade focuses, respectively. The hedging activities in each table are measured in two forms: 
1) The hedging amount (Column 6) - the total number of the companies which filed the Form 10-K report containing company's hedging information on currency risk within each SIC industry for each year;

2) The hedging dummy (Column 7) equals 1 if there is at least one company reporting any usage of hedging instruments under each SIC industry, 0 otherwise.

In each research design, summary descriptions of each column are as follows:

(1) The export pricing data classified with the 1972 SIC and the 1987 SEC's EDGAR SIC code.

(2) The sample years are from 1994 to 1996.

(3) The average export share is calculated for each SIC industry over the sample used in this study. The export share data used to select the top 10 and bottom 10 SIC product groups are available up to 1996.

(4) The total number of the companies which filed with a particular SIC code in SEC's EDGAR database.

(5) The total number of the companies from EDGAR database which filed Form 10-K reporting any usage of financial instruments within each SIC industry.

(6) The total number of the companies from EDGAR database which filed Form 10-K report containing company's hedging information on currency risk within each SIC industry. The number of hedging companies in each industry is used as a proxy of the hedging amount.

(7) The hedging dummy equals 1 if there is at least one company reporting any usage of hedging activity under each SIC industry; 0 otherwise.

(8) The industry title.

A balanced panel and bilateral export data to test the impact of hedging on pass-through includes 20 SIC industries, 3 years (1994-1996), 67 countries and 1,611 observations for the linked hedging export pricing dataset.

\section{Empirical Results}

The Hausman specification tests are performed to identify the appropriateness of using either fixed effect or random effect on the panel data analysis. Table 3 shows $\chi^{2}=1.81$ and $\chi^{2}=7.89$ for models with the hedging amount and the hedging dummy, respectively. Therefore, the null hypotheses cannot be rejected. In effect, the random effect regression models should be used.

Regarding the Breusch and Pagan Lagrangian multiplier tests, with a high value of $\chi^{2}$ statistics $\left(\chi^{2}=103.96\right.$ and $\chi^{2}=93.02$ ) in both models and at a 0 percent significance level, the null hypotheses assuming a zero variance in the cross section is rejected. According to the tests, our panel sample reveals that the individual differences from cross-sections have contributed to the various levels of the constant term. The test results suggest that the random effect regression model is appropriate for the empirical models. Hence, a panel random effect regression model is used to test a balanced pooled hedging data.

\subsection{Model with the hedging amount.}

The interaction between the hedging amount and the one-year-lagged exchange rate $\left(h g_{i t} e_{c, t-1}\right)$ in the hedging export pricing model (equation 6) reflects the impact of the hedging on the degree of pass-through. The estimation results are reported in column (2) of Table 3 . Through the interaction term $\left(h g_{i t} e_{c, t-1}\right)$, it is found that an increase in the hedging amount actually had significantly reduced the degree of pass-through. This supports the hypothesis and suggests the importance of hedging involvement in preventing any uncertainty from exchange rate fluctuations.

The coefficient estimate of the foreign demand elasticity interacting with one-year-lagged exchange rate is significant at $1 \%$. The negative sign is consistent with the prediction of a decrease in pass-through increases the foreign demand. In addition, other coefficient estimates in Table 3 are statistically insignificant. A more comprehensive hedging dataset with a longer time span should improve the results. A low R-squared in Table 3 is common under panel data regressions. For example, Mallick and Marques (2006) studied exchange rate pass-through with panel data and found R-squared in the range of 0.003 and 0.190 . Parsley (2003) used the panel pass-through estimations on a small open economy and obtained the adjusted R-squared in various models between 0.01 and 0.11 . While pooling the cross sections with time series, the data noise from the differences in country specific factors resulted in a low R-squared.

\subsection{Model with the hedging dummy.}

A hedging dummy, with and without hedging, interacting with the lagged exchange rates $\left(h g_{i t} e_{c, t-1}\right)$ is created to test the differential effect of these two sub-groups on pass-through with a sample of 20 SIC industries. Based on 
equation (6), the interaction dummy is not significantly different from zero. In other words, there is no differential impact between trades with and without hedging activities on the degree of pass-through according to the hedging data. The inconclusive results may be due in part to the number of financial hedging report in each SIC industry under study. The report of financial hedging against the risk of exchange rate fluctuations may not well represent the total industry hedging amount.

\section{Discussion}

This study is inspired by the partially-unexplained incomplete exchange rate pass-through phenomenon and to find any factor which would mute the impact of exchange rate fluctuations on prices. Other explanations of the pass-through puzzle may include multinational operations by related party trade and market segmentation by trade costs. The multinational corporations may use their network ability (related party trade) to reduce any exchange risk by operational or financial hedging. The distance of the international markets may be widened by exchange risk (identified as one of the trade costs) and thus the uncertainty creates an incentive to prevent the exchange risk by hedging engagements. Both activities aim to disconnect the relationship between exchange rates and prices. As a result, the world trade is financially and operationally able to prevent any trade risk over time, the degree of pass-through ought to be reduced gradually to zero.

\subsection{Practical Implications}

The finding that an increase in the hedging amount actually significantly reduces the degree of pass-through suggests the importance of hedging involvement in preventing any uncertainty from exchange rate fluctuations. The risk associated with fluctuations in currency exchange rates is usually managed by the use of derivative financial instruments to economically hedge or reduce the exposure to the exchange risk. The derivative financial instruments for hedging exchange risk could be forward contracts, futures contracts, currency options or currency swaps. For example, a U.S. exporter facing exchange risk (the trade value contracted in foreign currency i.e. Japanese yen) would enter a forward contract that obligates her/him to sell 10 million yens, for instance, one year from now in exchange for U.S. dollars at the current forward rate of 100 yens per dollar. In one year, when the exporter's trading partner pays the 10 million yens to the U.S. exporter, the forward contract ensures that it is exchanged for the U.S. dollar at an exchange rate of 100 yens per dollar, thus yielding 100,000 U.S. dollars $(10,000,000 / 100)$ regardless of what happens to future exchange rates. For a practical example, Wharton School's Surveys of Financial Risk Management at the University of Pennsylvania (Bodnar et.al.; 1995; 1996 and 1998) show that more than half of large firms hedge their exchange rate exposure in forward markets, and that large firms use foreign currency derivatives more than the small firms. Specifically, among U.S. non-financial firms the percentages of the firms that use derivatives are: large firms ( 69 percent), medium firms (41 percent), and small firms (12.33 percent).

\subsection{Contributions}

This paper contributes to the pass-through literature with a new aspect of theoretical framework. A hedging-augmented partial equilibrium pass-through model was derived to address the issue of price inertia phenomenon to exchange rate changes.

Strategic pricing. The theoretical framework of this paper is important to the pass-through study because under sufficiently high exchange rate volatility, competing firms will choose a flexible strategic pricing where no firm would commit its price or fix the price. Export pricing is mainly built on production cost, product substitutability, and destination market structure - the ability to markup. In a perfect competitive destination market the pricing decision depends solely on production cost. In an imperfectly competitive destination market, product substitutability and destination market structure govern the ability of exporters to compete in market share and be profitable. The less competitive the market is, the greater the profits the exporters can obtain. In this respect, export prices are equilibrated by market conditions. These arguments assume that the value of the currency-denominated export contract does not vary under any currency conversion conditions (either local-currency pricing or producer-currency pricing). If one introduces a condition of exchange rate fluctuation into the timely-contract invoicing, the future value of a new trade contract may be uncertain. The timely-contract invoicing is defined as a billing request that has to be met in a certain time frame, specified in the contract, after the traded goods are delivered. In other words, parties to the contract cannot delay or accelerate payments to deal with exchange rate changes. In this environment there will be a large exchange rate pass-through, as prices respond to actual exchange rate movements.

Hedging and international pricing. This study opens a new field for pass-through research. Researchers can investigate the financial hedging on the price and exchange rate relationship to confirm the hypothesis of the direct 
relationship between hedging engagements and international pricing. This paper is the initial step along this line of research and serves the opening foray to the research of hedging on the degree of exchange rate pass-through.

Elasticity of pass-through. Without taking hedging activities into account in pass-through research, the explanations for estimated elasticities of pass-through on aggregate firm behavior are problematic. For example, consider two trades with the same value from two identical firms. Assume the first firm uses hedging and therefore, has no currency risk exposure to pass through to its price (zero pass-through). By comparison, the second firm without hedging (full currency risk exposure) passes currency conversion risk to consumers in terms of the source country currency. It passes through partially if it has some market power (incomplete pass-through). Nothing will pass through if it is a price taker (zero pass-through). In the pass-through literature, the resulting zero pass-through in the case of the hedging firm could be confused with the price-taker case without hedging. By aggregating these two types of firm behavior, the pass-through estimates would obscure the true pricing behavior between these two seemingly identical firms.

\section{Conclusions}

This paper offers important implications on theory and contributions to the body of knowledge. The framework provides new insights into the understanding of the studies on exchange rate volatility, hedging, and pass-through. The result of the direct measurement of hedging on pass-through is supportive while the differential effects of different levels of hedging activities on the size of pass-through with the hedging dummy investigation were inconclusive. Given the importance of this model, further research agenda should be broadened by assessing the impact of the similar trade-oriented variable changes such as tariffs. With modern tools, it is possible to extend the model to include another important determinant of how prices respond to cost shocks over time. The results can be robust and reveal more profound relationship between exchange rates, prices and inflation.

Like any empirical research, there are few limitations to this study. This study collects some hedging information for a small portion of the U.S. export pricing data. The empirical research is often limited by the data availability. For example, the trade costs and the transportation charges are not usually available while the impact of non-tariff barriers is often difficult to estimate. In addition; the currency conversion risk is usually firm-specific. Given that data availability is surely a major problem, it may be easier to obtain hedging data from individual firms or a larger sample size for further research.

As noted in the earlier section regarding the non-stationarity in the time series context, there are ways to deal with the problem of the non-stationarity in the panel data series. For example, differencing time series and cointegration technique could be employed prior to running time-series regressions on data of a single destination country. In light of this fact, the preceding findings and implications notwithstanding, studies should continue into extraneous variable effects upon direct relationship between hedging activities and the degree of pass-through to U.S. dollar export prices.

\section{References}

Bodnar, G. M., Hayt, G. S., Marston, R. C. \& Smithson, C. W. (1995). Wharton survey of derivatives usage by U.S. non-financial firms, Financial Management, 24 (2), 104-114.

Bodnar, G. M., Hayt, G. S. \& Marston, R. C. (1996). 1995 Wharton survey of derivatives usage by U.S. non-financial firms, Financial Management, 25 (4), 113-133.

Bodnar, G. M., Hayt, G. S. \& Marston, R. C. (1998). 1998 Wharton survey of financial risk management by U.S. non-financial firms, Financial Management, 27 (4), 70-91.

Branson, W. H. \& Marston, R, C. (1989). Price and output adjustment in Japanese manufacturing, Working Paper Series 2878, National Bureau of Economic Research, http://www.nber.org/papers/w2878.

Chang, B.-K. \& Lapan, H. E. (2003). Price commitment vs. flexibility: the role of exchange rate uncertainty and its implications for exchange rate pass-through, Review of International Economics, 11 (4), 697-711.

Devereux, M. B. \& Engel, C. (1998). Fixed vs. floating exchange rates: how price setting affects the optimal choice of exchange-rate regime, Working Paper Series 6867, National Bureau of Economic Research, http://www.nber.org/papers/w6867.

Dornbusch, R. (1987). Exchange rates and prices, the American Economic Review, 77 (1), 93-106.

Engel, C. (1999). On the foreign exchange risk premium in sticky-price general equilibrium models, Working Paper Series 7067, National Bureau of Economic Research, http://www.nber.org/papers/w7067. 
Feenstra, R. C. \& Kendall, J. D. (1991). Exchange rate volatility and international prices, Working Paper Series 3644, National Bureau of Economic Research, http://www.nber.org/papers/w3644.

Giovannini, A. (1988). Exchange rates and traded goods prices, Journal of International Economics, 24, 45-68.

Hooper, P. \& Kohlhagen, S. W. (1978). The effect of exchange rate uncertainty on the prices and volume of international trade, Journal of International Economics, 8, 483-511.

Hooper, P. \& Mann, C. L. (1989). Exchange rate pass-through in the 1980s: the case of U.S. imports of manufactures, Brookings Papers on Economics Activity, 1, 297-337.

Huang, J.-C. \& Brahmasrene, T. (2004). Do size and sector matter in the pass-through to U.S. export pricing? Journal of Business and Economics Research, 5 (1 \& 2).

Huang, J.-C. \& Brahmasrene, T. (2009). A model of exchange risk and exchange rate pass-through, Asian-African Journal of Economics and Econometrics, 9 (2).

Mallick, S. \& Marquesn, H. (2006). Sectoral exchange rate pass-through: testing the impact of policy reforms in India, Scottish Journal of Political Economy, 53 (2), 280-303.

Mann, C. L. (1986). Prices, profit margins, and exchange rates, Federal Reserve Bulletin, 72, 366-379.

Mann, C. L. (1989). The effects of exchange-rate trends and volatility on export prices: industry examples from Japan, Germany, and the United States, Weltwirtschaftliches Archiv, 125 (3), 588-618.

Obstfeld, M. \& Rogoff, K. (1998). Risk and exchange rates, Working Paper Series 6694, National Bureau of Economic Research, http://www.nber.org/papers/w6694.

Parsley, D. C. (2003). Exchange rate pass-through in a small open economy: panel evidence from Hong Kong. International Journal of Finance \& Economics, 8 (2), 99-108.

Parsley, D. C. \& Cai, Z. (1995). Exchange rate uncertainty and traded goods prices, International Economic Journal, 9 (2), 27-35.

Table 1. The 10 Highest U.S. SIC Industry Export Share Hedging Data

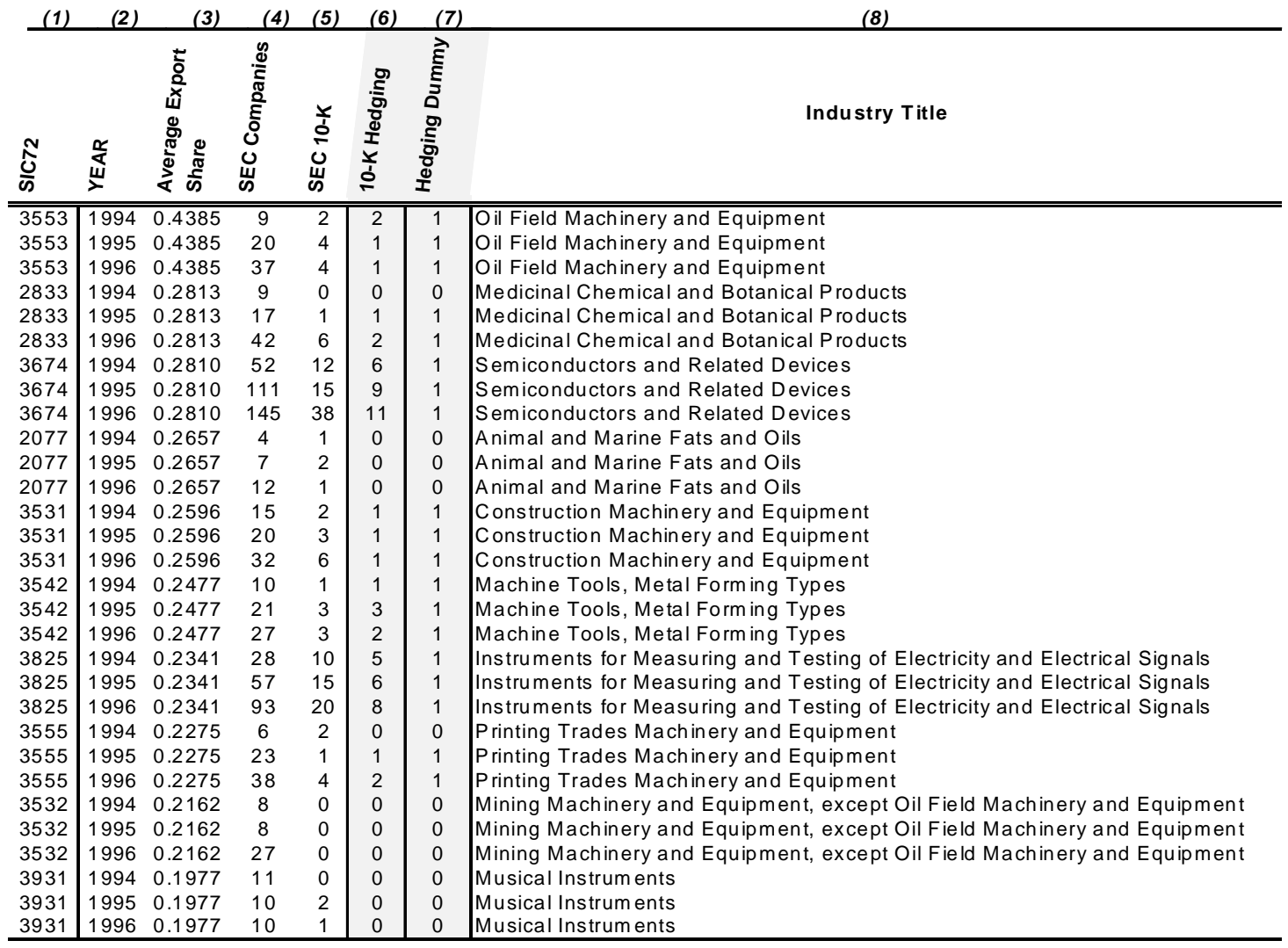


Table 2. The 10 Lowest U.S. SIC Industry Export Share Hedging Data

\begin{tabular}{|c|c|c|c|c|c|c|c|}
\hline (1) & (2) & (3) & (4) & $(5)$ & (6) & (7) & (8) \\
\hline$\frac{N}{\tilde{N}}$ & $\underset{⿱ 亠 䒑}{\frac{\alpha}{x}}$ & 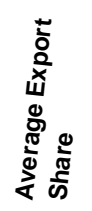 & 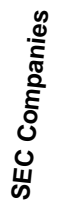 & 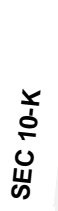 & 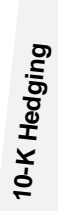 & 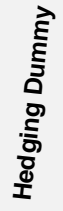 & Industry Title \\
\hline$\overline{\overline{3442}}$ & 1994 & $\overline{0.0114}$ & $\overline{112}$ & 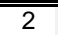 & 0 & $\overline{0}$ & TMetal Doors, Sash, Frames, and Trim \\
\hline 3442 & 1995 & 0.0114 & 16 & 2 & 1 & 1 & Metal Doors, Sash, Frames, and Trim \\
\hline 3442 & 1996 & 0.0114 & 18 & 2 & 1 & 1 & Metal Doors, Sash, Frames, and Trim \\
\hline 3444 & 1994 & 0.0069 & 5 & 1 & 0 & 0 & Sheet Metal Work \\
\hline 3444 & 1995 & 0.0069 & 14 & 1 & 0 & 0 & Sheet Metal Work \\
\hline 3444 & 1996 & 0.0069 & 29 & 1 & 0 & 0 & Sheet Metal Work \\
\hline 3999 & 1994 & 0.0046 & 11 & 5 & 0 & 0 & Manufacturing Industries, Not Elsewhere Classified \\
\hline 3999 & 1995 & 0.0046 & 34 & 7 & 1 & 1 & Manufacturing Industries, Not Elsewhere Classified \\
\hline 3999 & 1996 & 0.0046 & 66 & 10 & 1 & 1 & Manufacturing Industries, Not Elsewhere Classified \\
\hline 3524 & 1994 & 0.0043 & 6 & 1 & 1 & 1 & Garden Tractors and Lawn and Garden Equipment \\
\hline 3524 & 1995 & 0.0043 & 8 & 1 & 1 & 1 & Garden Tractors and Lawn and Garden Equipment \\
\hline 3524 & 1996 & 0.0043 & 17 & 2 & 0 & 0 & Garden Tractors and Lawn and Garden Equipment \\
\hline 2082 & 1994 & 0.0043 & 5 & 2 & 2 & 1 & Malt Beverages \\
\hline 2082 & 1995 & 0.0043 & 10 & 1 & 1 & 1 & Malt Beverages \\
\hline 2082 & 1996 & 0.0043 & 37 & 2 & 1 & 1 & Malt Beverages \\
\hline 3411 & 1994 & 0.0039 & 15 & 5 & 1 & 1 & Metal Cans \\
\hline 3411 & 1995 & 0.0039 & 25 & 2 & 0 & 0 & Metal Cans \\
\hline 3411 & 1996 & 0.0039 & 37 & 4 & 1 & 1 & Metal Cans \\
\hline 2086 & 1994 & 0.0031 & 10 & 4 & 2 & 1 & Bottled and Canned Soft Drinks and Carbonated Waters \\
\hline 2086 & 1995 & 0.0031 & 14 & 2 & 2 & 1 & Bottled and Canned Soft Drinks and Carbonated Waters \\
\hline 2086 & 1996 & 0.0031 & 38 & 4 & 1 & 1 & Bottled and Canned Soft Drinks and Carbonated Waters \\
\hline 3499 & 1994 & 0.0002 & 24 & 5 & 1 & 1 & Fabricated Metal Products, Not Elsewhere Classified \\
\hline 3499 & 1995 & 0.0002 & 50 & 8 & 3 & 1 & Fabricated Metal Products, Not Elsewhere Classified \\
\hline 3499 & 1996 & 0.0002 & 78 & 11 & 2 & 1 & Fabricated Metal Products, Not Elsewhere Classified \\
\hline 2621 & 1994 & 0.0001 & 41 & 16 & 5 & 1 & Paper Mills, Except Building Paper Mills \\
\hline 2621 & 1995 & 0.0001 & 60 & 14 & 5 & 1 & Paper Mills, Except Building Paper Mills \\
\hline 2621 & 1996 & 0.0001 & 89 & 14 & 2 & 1 & Paper Mills, Except Building Paper Mills \\
\hline 3861 & 1994 & 0.0001 & 18 & 3 & 2 & 1 & Photographic Equipment and Supplies \\
\hline 3861 & 1995 & 0.0001 & 27 & 4 & 2 & 1 & Photographic Equipment and Supplies \\
\hline 3861 & 1996 & 0.0001 & 73 & 13 & 3 & 1 & Photographic Equipment and Supplies \\
\hline
\end{tabular}

Table 3. The Quantitative and Qualitative Export Pricing Model Estimations

\begin{tabular}{rll}
\hline \multicolumn{1}{c}{$(1) \quad$} & $(2)$ & $(3)$ \\
Variables & $\begin{array}{l}\text { Export Pricing Model with the } \\
\text { Hedging Amount }\end{array}$ & $\begin{array}{l}\text { Export Pricing Model with the } \\
\text { Hedging Dummy }\end{array}$ \\
\hline Constant & $-0.0431(0.419)$ & $-0.0427(0.404)$ \\
$e_{c, t-1}$ & $-0.0475(0.664)$ & $0.3385(0.367)$ \\
$h g_{i t} e_{c, t-1}$ & $0.1665(0.017)^{* *}$ & $-0.1872(0.609)$ \\
$\left|\varepsilon_{x, i t}^{d}\right|$ & $-5.5349(0.007)^{* * *}$ & $-16.9244(0.000)^{* * *}$ \\
$p_{c t}^{f}$ & $-0.0249(0.894)$ & $0.0194(0.933)$ \\
$g d p_{c t}^{f}$ & $0.0983(0.915)$ & $0.4577(0.616)$ \\
$p c_{i, t-1}$ & $0.6312(0.243)$ & $0.4167(0.399)$ \\
$p g_{t}$ & $0.2209(0.470)$ & $0.1040(0.629)$ \\
Observations & 1,611 & 1,611 \\
R-Squared (within) & 0.0070 & 0.0448 \\
Wald Test & $\chi^{2}=13.18(0.068)^{* *}$ & $\chi^{2}=54.41(0.000)^{* * *}$ \\
Hausman Specification Test & $\chi^{2}=1.81(0.9364)$ & $\chi^{2}=7.89(0.246)$ \\
Breusch and Pagan LM Test & $\chi^{2}=103.96(0.000)^{* * *}$ & $\chi^{2}=93.02(0.000)^{* * *}$ \\
\hline
\end{tabular}

Note:

a. The numbers in parentheses are the probability value (p-value).

b. *,**, and *** are the significant levels at $10 \%, 5 \%$, and $1 \%$, respectively. 